\title{
Exploring the Biotic Stress Tolerance Potential of Heavy Metal Tolerate Rhizobacteria Isolated from Mines Area and Landfill Site
}

\section{Sarita Sharma, Rathod Zalak R and Saraf Meenu $\mathbf{S}^{*}$}

Department of Microbiology and Biotechnology, University of School of Sciences, Gujarat University Ahmedabad, Gujarat, India

*Corresponding Author: Saraf Meenu S, Department of Microbiology and Biotechnology, University of School of Sciences, Gujarat University Ahmedabad, Gujarat, India.
Received: December 22, 2021

Published: January 12, 2022

(C) All rights are reserved by Saraf Meenu S., et al.

\section{Abstract}

Agriculture is critical to any economy, particularly those in developing and developing countries. Increased abiotic and biotic stressors have a negative impact on crop output around the world. Microorganisms that live in the Rhizospheric zone of plant soil are known to help alleviate these pressures, resulting in increased crop productivity and output. The goal of this study was to study the antibacterial and antifungal activity of Rhizospheric bacteria, which is isolated from the rhizosphere soil of the Zawar mines area in Udaipur, Rajasthan, India, and the Pirana landfill site in Ahmedabad, Gujarat, India, and demonstrating the ability to withstand both abiotic (heavy metal) and biotic stress. Six of the 91 bacterial isolates that showed strong tolerance to heavy metal were chosen for further investigation. Three from the Zawar mines area and three from the paranal and fill site showed great resistance to heavy metal, and their biotic stress tolerance was explored further. Antifungal activity was tested using Macrophomina phaseolina, Fusarium oxysporium (Pink), Fusarium oxysporium (White), Aspergillus niger, and Trichoderma spp. Antibacterial activities of the three chosen bacterial strains were also evaluated against Gram-positive bacteria (Staphylococcus aureus, Bacillus subtilis, and Bacillus pumilus). SMHMZ4 and SMHMP23 have the most antagonistic activity among the six bacterial strains investigated.

Keywords: Biocontrol; Plant Growth Promoting Rhizobacteria; Antibacterial Activity; Antifungal Activity

\section{Introduction}

Agriculture production is hampered by a variety of problems including agricultural land loss, soil contamination, environmental deterioration, and illnesses. Excessive use of synthetic pesticides to combat pests and diseases has also surfaced as a growing source of worry for current agricultural practises [5]. As a result, attention has switched to a crop improvement and disease management method that is both ecologically friendly and commercially viable. The use of naturally occurring free-living rhizobacterial strains known as plant growth-promoting rhizobacteria (PGPR), which colonise and multiply along the surface or cortex of the transplanted plant's root, has been found to be a safe and viable alternative. Pseudomonas and Bacillus species have been identified to be promising agents, and their use as PGPR has been described in recent years.
Furthermore, many of these organisms induced systemic resistance in host plants against a variety of critical agricultural diseases $[2,5,10]$. Antibiosis, parasitism, predation, competition and scavenging nutrients and elements, particularly iron, hormone generation, and defence system enhancement are some of the techniques these organisms use to attain these goals, either directly or indirectly. Pseudomonas aeruginosa is a free-living bacterium species among fluorescent Pseudomonas that has been economically utilised as an eco-friendly viable plant growth promoting rhizobacteria as well as a biocontrol agent in recent years [6]. $P$. aeruginosa and other fluorescent pseudomonas produce a number of metabolites that play an important role in growth promotion and disease management. P. aeruginosa species have been shown to produce iron chelating chemicals such as siderophore and a vari- 
ety of antibiotics with potential applications in crop enhancement and disease management [3]. The ability to withstand agroclimatic changes, the capability for persistent colonisation, and the ability to multiply on the root or root cortex region of imported plants are all regarded advantages when comparing these organisms to the rest of the flora. Extraction, purification, and characterization of bioactive metabolites produced by these organisms could help researchers better understand the chemical benefits of these organisms, potentially leading to new approaches to control plant infections. Natural products have consistently been the most successful source of lead compounds that have many applications in medicine, pharmacy, and agriculture throughout history [15].

The majority of antibiotics now in use for the treatment of various infectious diseases come from microbial natural products. Secondary metabolites produced by several terrestrial bacteria have been shown to suppress microorganisms competing for the same resources [15]. Bacterial resistance, on the other hand, arises when or shortly after an antimicrobial agent is released to the market [5]. As a result, new antimicrobial agents are always needed to compete with infections. In this regard, microbial secondary metabolites continue to be the most important source of novel and prospective therapeutic compounds. Plants and bacteria coexist or compete for survival, and their cooperative interactions are important in adjusting to metalliferous conditions, so they can be studied to improve microbe-assisted phytoremediation. Plant root exudates provide nutrients and energy to soil microbes, with whom they form complex communication networks.

Beneficial bacteria and fungi that act as plant growth promoting microorganisms (PGPMs) may alleviate metal phytotoxicity and stimulate plant growth in two ways: indirectly through the induction of defence mechanisms against phytopathogens, and/or directly through the solubilization of mineral nutrients (nitrogen, phosphate, potassium, iron, etc.), production of plant growth promoting substances (e.g. phytohormones), and secretion of specific enzymes (e.g., 1-aminocyclopropane1-carboxylate deaminase). Acidification, precipitation, chelation, complexation, and redox reactions are among ways that PGPM might alter metal bioavailability in soil $[4,9,12,13]$. The goal of this study was to look at the role of a heavy metal tolerant rhizobacteria isolated from mines and landfills, as well as its antimicrobial activity against five fungus strains and four bacterial strains.
Material and Methods

\section{Isolation of rhizobacteria}

A total of 51 rhizosphere bacteria were recovered from the Zawar mines in Udaipur, Rajasthan $[13,14]$, while 40 rhizosphere bacteria were retrieved from the Pirana waste site in Ahmedabad, Gujarat. Heavy metal resistance was better in the bacterial colonies SMHMZ2, SMHMZ4, and SMHMZ46 from the Zawar mines, as well as SMHMP4, SMHMP23, and SMHMP38 from the Pirana waste site $[14,15]$.

\section{Fungal pathogens}

Macrophomina phaseolina, Fusarium oxysporium (Pink), Fusarium oxysporium (White), Aspergillus niger, and Trichoderma spp. were the fungal pathogens used in this study.

\section{Bacterial pathogens}

Staphylococcus aureus, Bacillus subtilis, and Bacillus pumilus were the bacterial pathogens used in this study.

\section{Media and chemicals}

Nutrient agar compositions such as Peptone, Beef extract, Yeast extract, Agar powder, and Potato Dextrose Agar were used in this experiment, and they came from HiMedia Laboratories in Mumbai, India. Fine Chemicals (P) Ltd. in New Delhi, India, provided the sodium chloride and maltose.

Antagonistic activity of the selected strain

Antibacterial activity

The antibacterial activity of specific bacterial strains was assessed using the agar diffusion method. Bacterial strains were grown in Nutrient Broth (NB) medium and incubated at $37^{\circ} \mathrm{C}$ for 24 hours to test their antibacterial activity. Antimicrobial activity of selected isolates was tested using Nutrient Agar (NA) medium Petri plates. On $\mathrm{N}$-agar plates, cell suspension of $24 \mathrm{~h}$ activated target strains (Staphylococcus aureus, Bacillus subtilis, and Bacillus pumilus) were disseminated.

After that, a sterile cork borer was used to make a $5 \mathrm{~mm}$ diameter well in the NA plates, which was then filled with cell free supernatant from bacterial isolates. At $37^{\circ} \mathrm{C}$, these plates were incubated for 24 hours [8]. The data was expressed as mean standard deviation after three repetitions of each experiment. 


\section{Antifungal properties}

Macrophomina phaseolina, Fusarium oxysporium (Pink), Fusarium oxysporium (White), Aspergillus niger, and Trichoderma spp. were the fungal strains employed in this study. These fungi were first grown on Potato dextrose agar (PDA) plates and incubated for 5 days at $28^{\circ} \mathrm{C}$. The agar diffusion method was used to test the antifungal activity of the bacterial broth. For this, a $1 \mathrm{~cm}^{2}$ fungal plug from previously active fungal cultures was inoculated in the centre of a PDA plate. Then, using a sterile cork borer, wells of $5 \mathrm{~mm}$ diameter were made in the PDA plates, and these wells were filled with cell free supernatant of bacterial isolates. The plates were then incubated at $28^{\circ} \mathrm{C}$ for 72 hours, with antifungal activity being checked every 24 hours and the results recorded [8]. The data was expressed as mean standard deviation after three repetitions of each experiment.

\section{Result and Discussion}

The Rhizospheric soil sample collected from Zawar mines area, Udaipur, Rajasthan, India, and Pirana waste site area, Ahmedabad, Gujarat, India yielded a total of 91 bacterial strains. Six rhizobacterial strains, three from the Zawar mines region (SMHMZ2, SMHMZ4, and SMHMZ46), and three from the Pirana dump site area (SMHMP4, SMHMP23, and SMHMP38), showed great potential against three heavy metals $\left(\mathrm{Ni}^{2+}, \mathrm{Pb}^{2+}\right.$, and $\left.\mathrm{Cd}^{2+}\right)$ and were investigated for antifungal activity. Antibacterial activity was examined on three isolates that showed great potential to survive various abiotic stressors (heavy metals) and antifungal activity. Three isolates (SMHMZ2, SMHMZ4, and SMHMP23) have antifungal activity against Aspergillus niger, and four isolates (SMHMZ2, SMHMZ4, SMHMP4, and SMHMP23) have antifungal activity against Fusarium oxysporium (White), Fusarium oxysporium (Pink), Macrophomina phaseolina, and four isolates (SMHMZ2, SMHMZ4, SMHMZ46, and SMHMP38) has antifungal activity against Trichoderma spp. (Figure 2- A-E). Antibacterial activity against all three pathogenic bacteria, Bacillus subtilis, Staphylococcus aureus, and Bacillus pumilus, is best in the isolates SMHMZ4 and SMHMP23 (Figure 1 (A-D).

Individual strains of plant growth promoting rhizobacteria (PGPR) are screened for broad-spectrum disease suppression in vitro and in planta by Liu., et al. [8] In vitro, 28 of 196 strains inhibited eight distinct pathogens in a preliminary screen. In a secondary screen, these 28 strains were found to have broad spectrum an-

\begin{tabular}{|l|c|c|c|}
\hline Isolates & \multicolumn{3}{|c|}{ Zone of Inhibition (mm) } \\
\hline & $\begin{array}{c}\text { Bacillus } \\
\text { subtilis }\end{array}$ & $\begin{array}{c}\text { Staphylococcus } \\
\text { aureus }\end{array}$ & $\begin{array}{c}\text { Bacillus } \\
\text { pumilus }\end{array}$ \\
\hline SMHMZ2 & - & - & - \\
\hline SMHMZ4 & 38 & 24.5 & 25.5 \\
\hline SMHMZ46 & - & - & - \\
\hline SMHMP4 & - & - & - \\
\hline SMHMP23 & 32.5 & 22 & 22.5 \\
\hline SMHMP38 & - & - & - \\
\hline
\end{tabular}

Table 1: Antimicrobial activity of bacterial isolates against test organism.

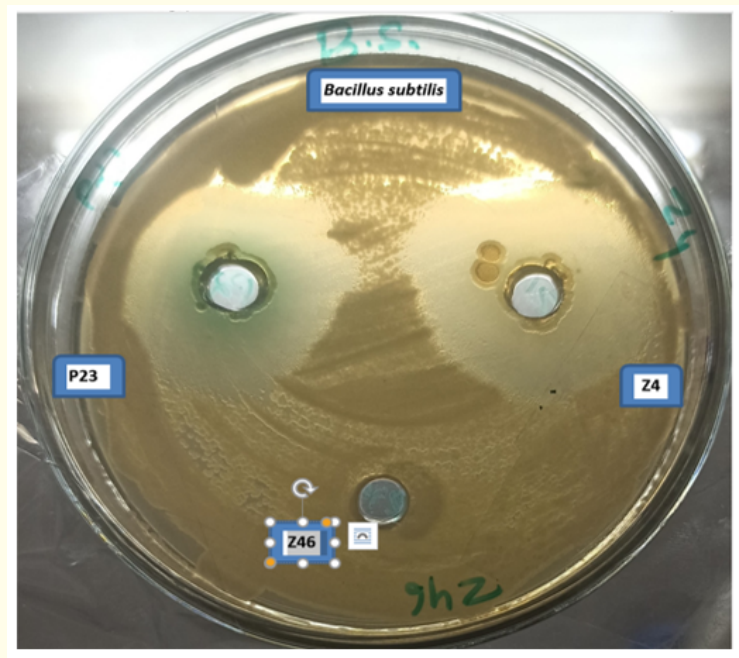

(a)

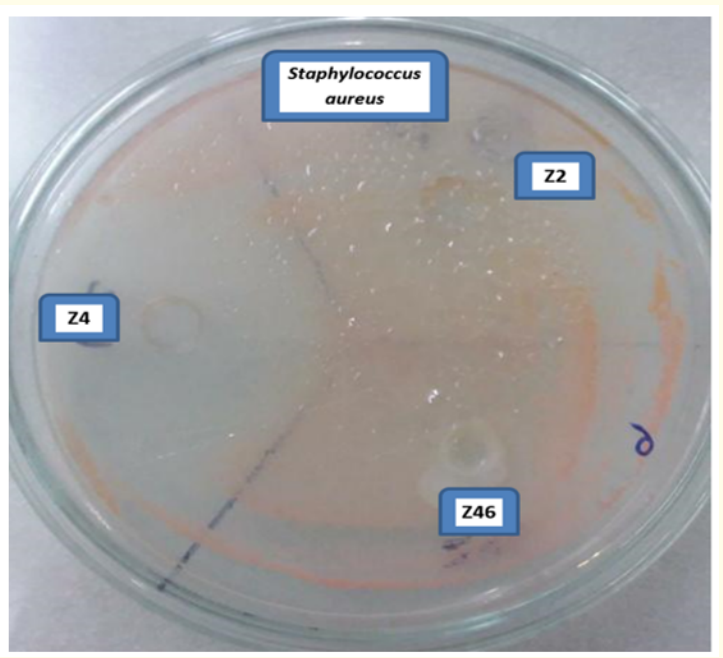

(b) 


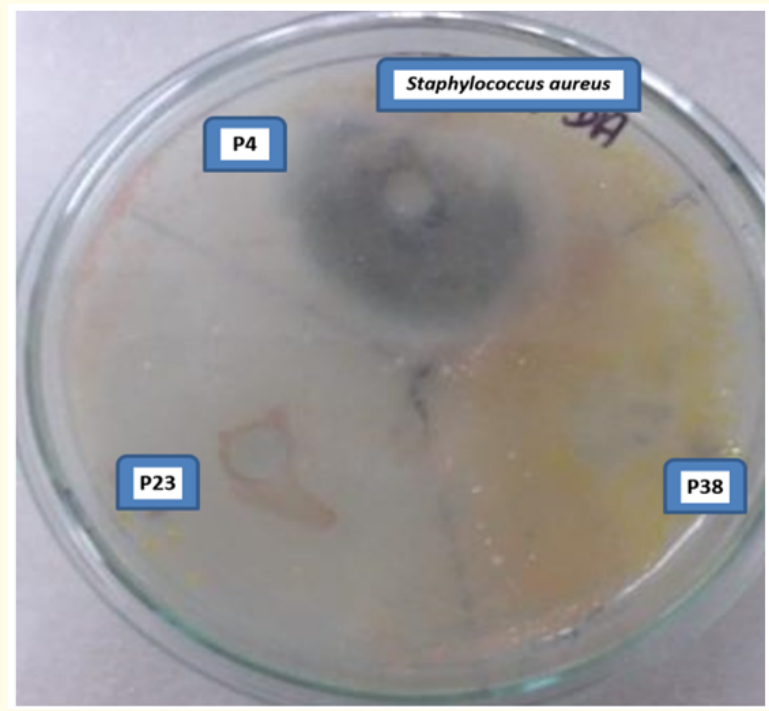

(c)

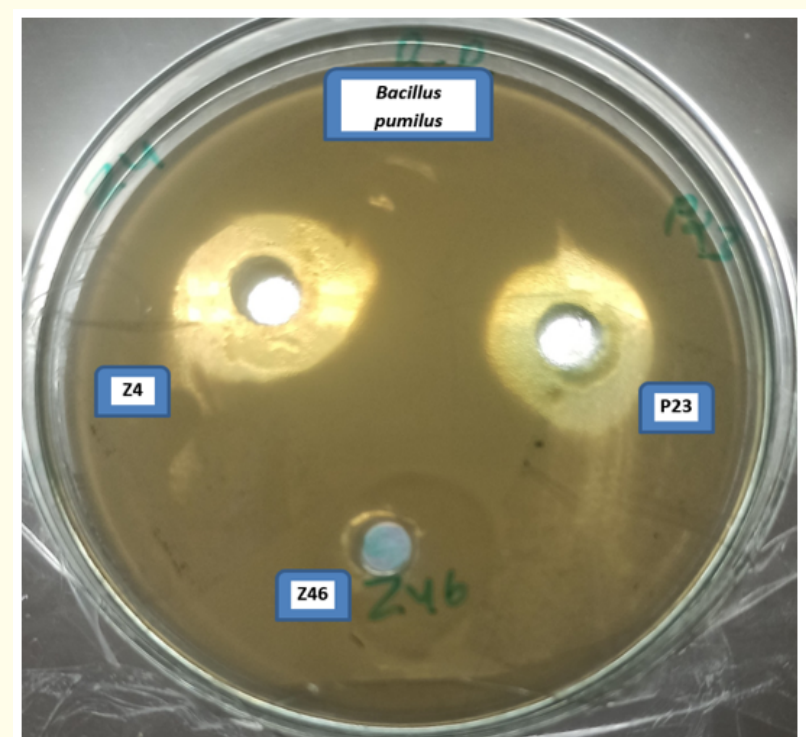

(d)

Figure 1: Showing antibacterial activity of selected strains against (a) Bacillus subtilis (b) S.aureus (c) S.aureus (d) Bacillus pumilus.

\begin{tabular}{|l|c|c|c|c|c|}
\hline \multirow{2}{*}{ Isolates } & \multicolumn{5}{|c|}{ Zone of Inhibition (mm) } \\
\cline { 2 - 6 } & A. niger & $\begin{array}{c}\text { F Oxysporum } \\
\text { (Pink) }\end{array}$ & $\begin{array}{c}\text { F. Oxysporum } \\
\text { (White) }\end{array}$ & M. phaseolina & Trichoderma spp. \\
\hline Z2 & 41 & 30.6 & 34.6 & 15 & 12 \\
\hline Z4 & 57.6 & 43.8 & 50.2 & 29 & 22 \\
\hline Z46 & - & 10 & 15.6 & 12.5 & 12 \\
\hline P4 & - & 39.8 & 12 & 18.5 & - \\
\hline P23 & 43 & 44.8 & 38.9 & 22.5 & 24 \\
\hline P38 & - & - & 18 & - & \\
\hline
\end{tabular}

Table 2: Antagonistic activity of bacterial isolates against fungal pathogens.

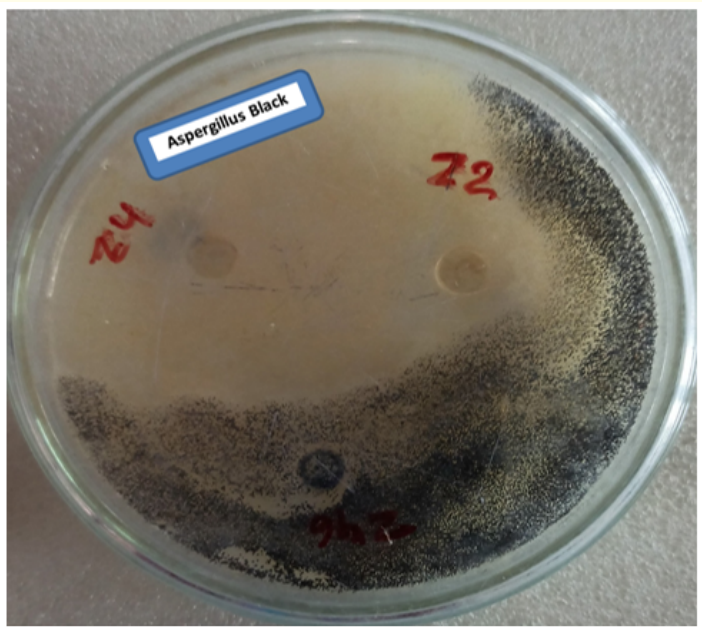

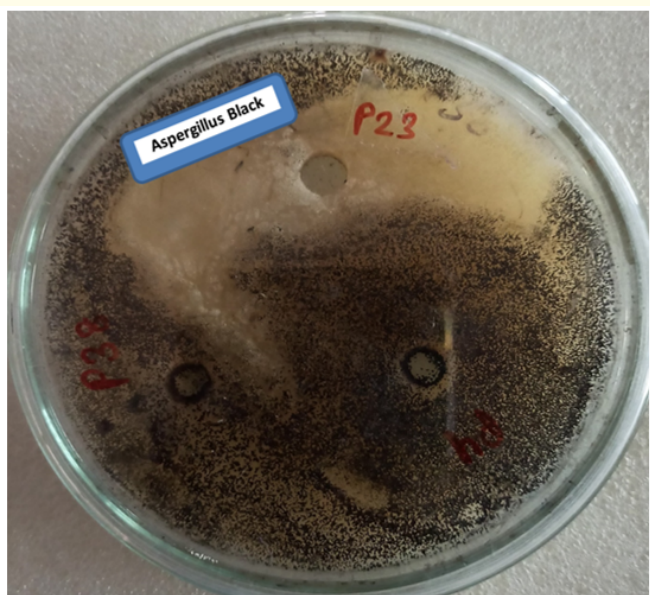

Figure 2(a) Aspergillus niger

Citation: Saraf Meenu S., et al. "Exploring the Biotic Stress Tolerance Potential of Heavy Metal Tolerate Rhizobacteria Isolated from Mines Area and Landfill Site". Acta Scientific Microbiology 5.2 (2022): 31-37. 

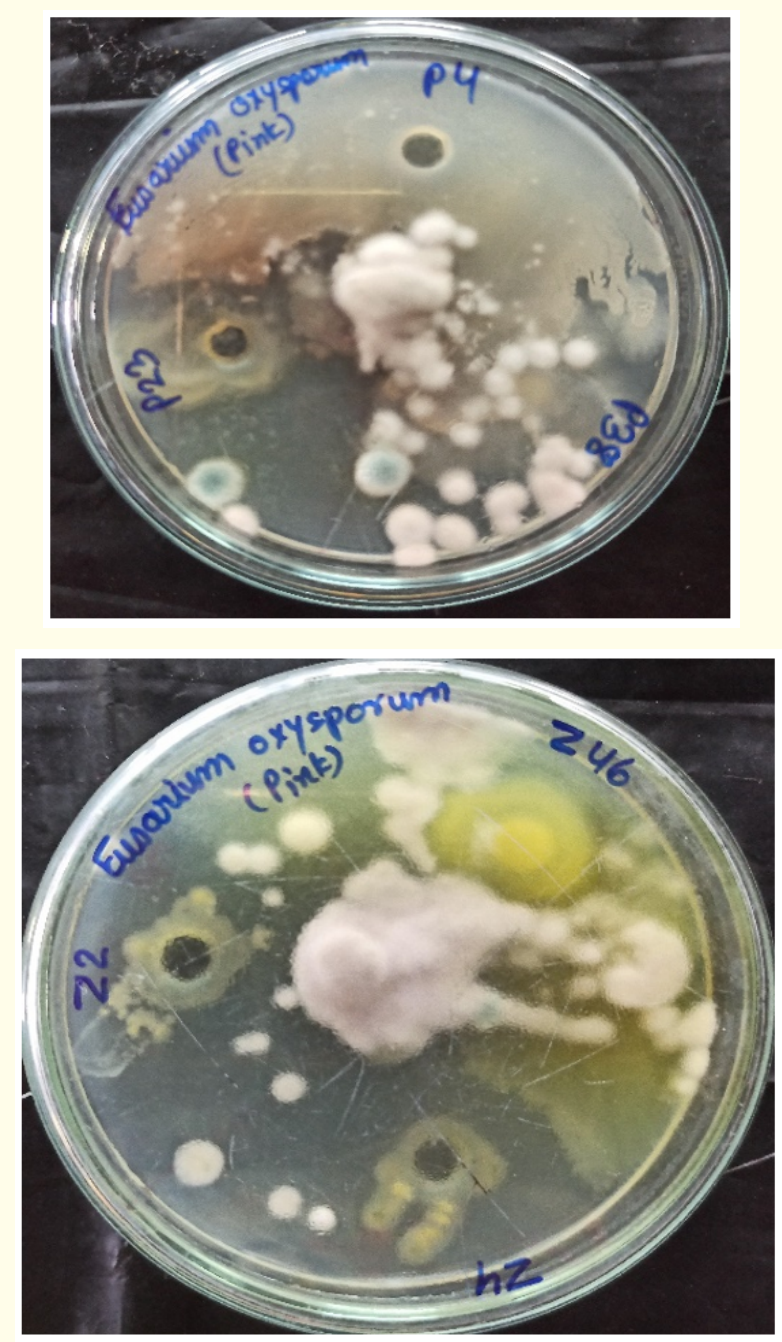

Figure 2(b) Foxysporium (Pink)

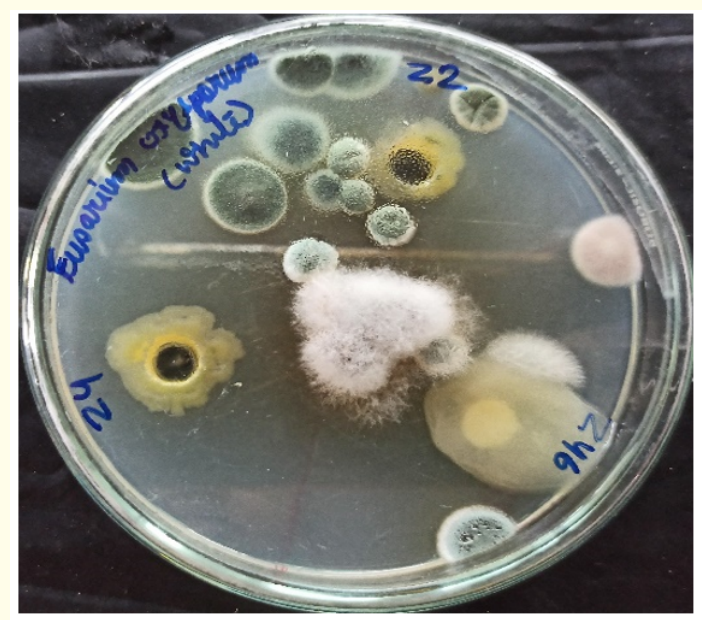

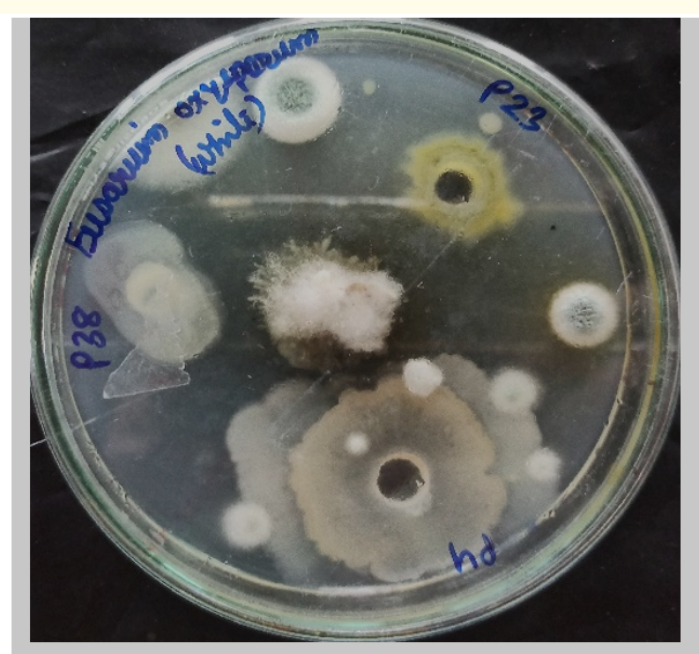

Figure 2 (c) Foxysporium (white)
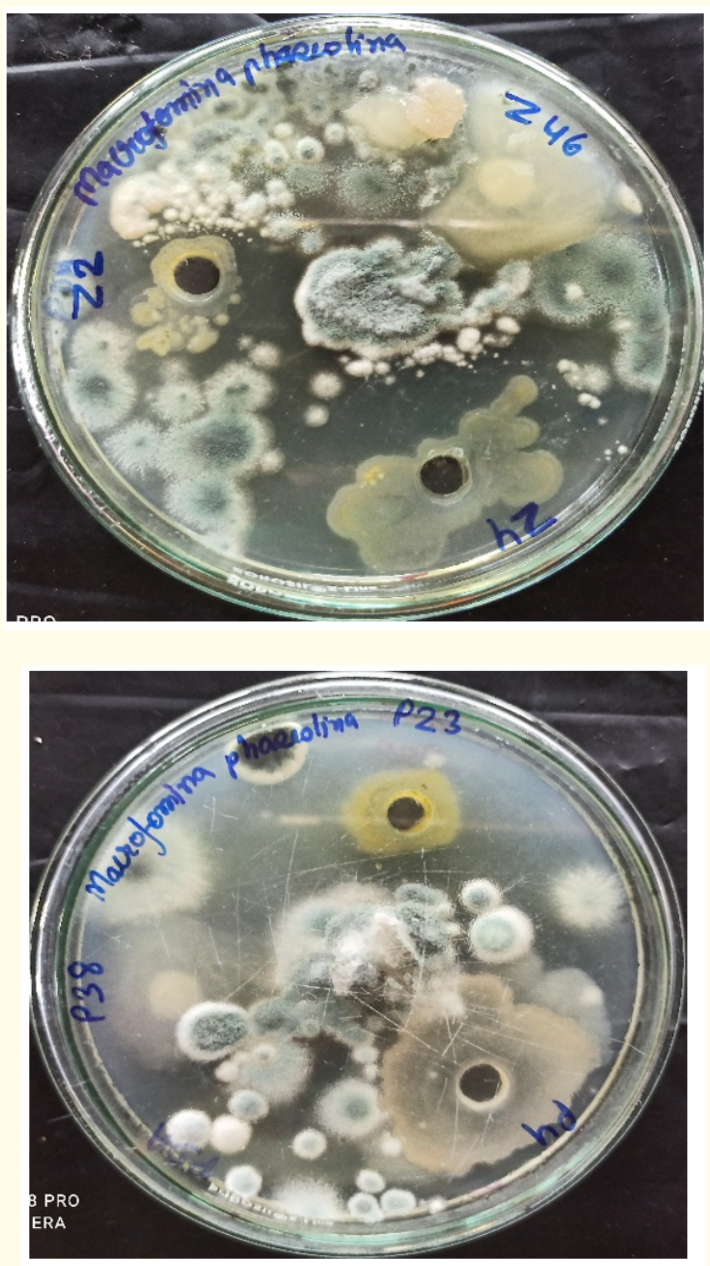

Figure 2(d) Macrofomina phaseolina 

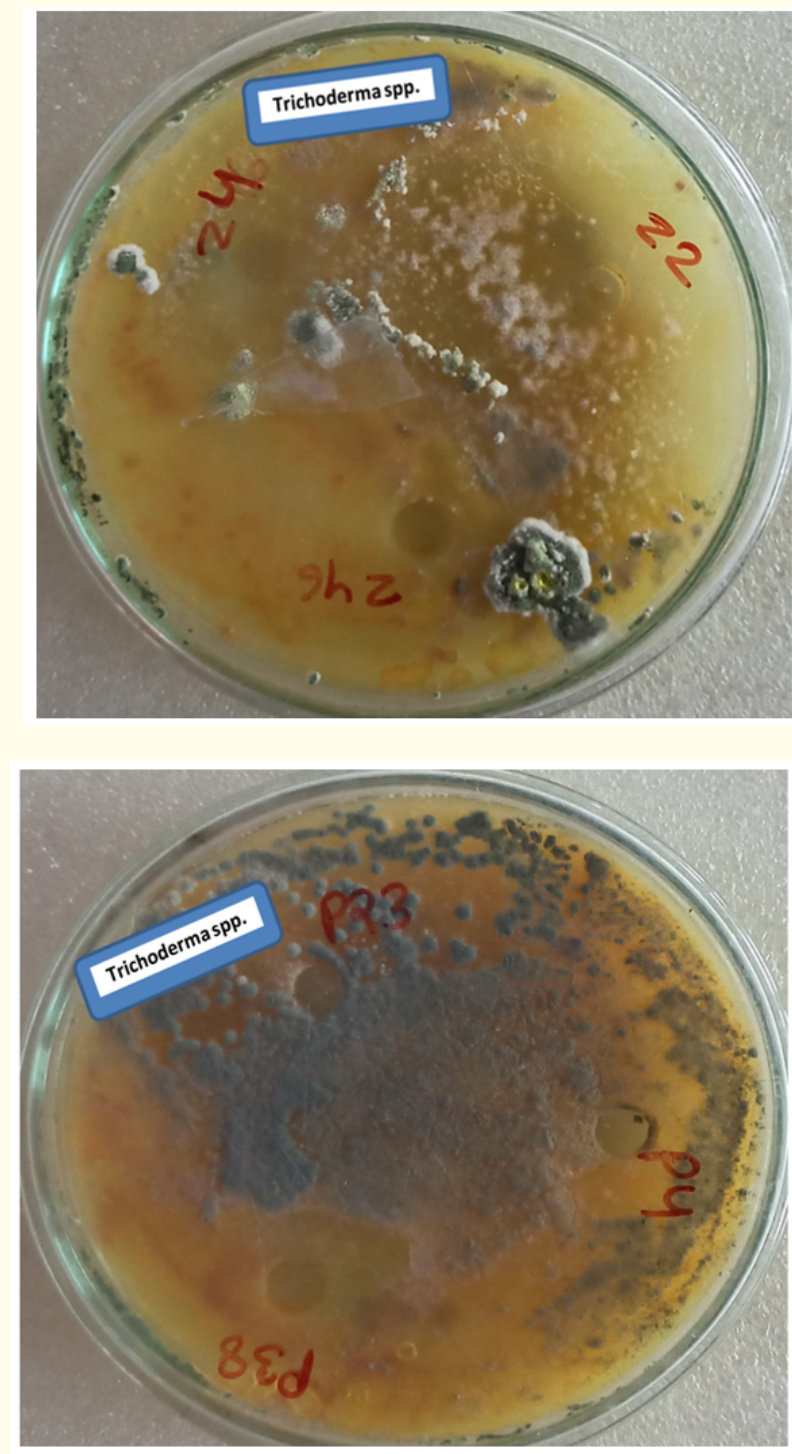

Figure 2(e) Trichoderma spp.

Figure 2: Showing Antagonistic Activity of bacterial strain against (a) Aspergillus niger (b) F.oxysporium (Pink) (c) Foxysporium (white) (d) Macrofomina phaseolina

(e) Trichoderma spp.

tagonistic activity against six pathogen genera (R. solani, Fusarium oxysporum f. sp. lycopersici, Fusarium oxysporum f. sp. vasinfectum, $X$. axonopodis pv. vesicatoria, and Pseudomonas syringae pv. tomato), and Nitrogen fixation, phosphate solubilization, indole-3-acetic acid production, siderophore production, and biofilm development were all produced by 24 of the 28 strains.
According to Xu., et al. [17] a total of 60 P. aeruginosa strains were tested. In all, 35 P. aeruginosa isolates demonstrated a significant inhibitory effect against $S$. aureus (ATCC 25923), while the other $P$. aeruginosa strains had no effect. P. aeruginosa PA06 and PA46 demonstrated the highest inhibitory zone effects, while PA01 and PA22 had no impact. Additional studies revealed that PA06 and PA46 had significant inhibitory effects against methicillin-resistant S. aureus (MRSA, Gram-positive cocci), vancomycin intermediateresistant S. aureus (VISA, Gram-positive cocci), and other Grampositive cocci.

According to Kumar., et al. [7] 18 of the 40 isolates identified as P. fluorescens produced antifungal metabolites that showed strong antifungal activity against Fusarium oxysporium and Rhizoctonia bataticola. Sadfi., et al. [11] discovered that in the presence of $B$. cereus $X 16$, the fungus $F$. roseum was unable to grow.

\section{Conclusion}

We were able to isolate rhizobacteria that are resistant to a variety of heavy metals (abiotic stress) and biotic stresses as a result of our research. Antifungal and antibacterial activities are present in these isolates. These isolates can be employed as bio inoculants in places where abiotic stress is present. These microbial inoculants can aid in the fight against pathogenic bacteria and fungi-caused plant diseases. SMHMZ4 and SMHMP23 isolates have good antagonistic activity against pathogenic bacteria and fungi that cause significant crop damage.

\section{Acknowledgments}

I am grateful to my Guide Professor (Dr.) Meenu Saraf, Head of Department of Microbiology and Biotechnology and Director of University School of Sciences, Gujarat University, Gujarat, India, and Faculty member of Department of Microbiology and Biotechnology, Gujarat University, Gujarat, India.

\section{Conflicts of Interest}

We declare that there are no conflicts of interest.

\section{Bibliography}

1. Bax RP., et al. "Antibiotic resistance-what can we do?" Nature Medicine 4.5 (1998): 545-546.

2. Bhattacharyya PN and Jha DK. "Plant growth-promoting rhizobacteria (PGPR): emergence in agriculture". World Journal of Microbiology and Biotechnology 28.4 (2012): 1327-1350. 
3. Compant S., et al. "Use of plant growth-promoting bacteria for biocontrol of plant diseases: principles, mechanisms of action, and future prospects". Applied and Environmental Microbiology 71.9 (2005): 4951-4959.

4. Dabhi J., et al. "Bioremediation of Heavy Metals: A brand New Methodology to Sustainable Agriculture". International Journal of Innovative Research in Science, Engineering and Technology (IJIRSET) 10.6 (2021): 6031-6049.

5. Dutta S and Podile RA. "Plant growth promoting rhizobacteria (PGPR): the bugs to debug the root zone". Critical Reviews in Microbiology 36.3 (2010): 232-244.

6. Höfte M., et al. "Pyoverdin production by the plant growth beneficial Pseudomonas strain 7NSK 2: Ecological significance in soil". Plant and Soil 130.1 (1991): 249-257.

7. Kumar NR., et al. "Current Science". Journal of Plant Pathology 83 (2002): 101-118.

8. Liu K., et al. "Selection and assessment of plant growth-promoting rhizobacteria for biological control of multiple plant diseases". Phytopathology 107.8 (2017): 928-936.

9. Ma Y., et al. "Biochemical and molecular mechanisms of plantmicrobe-metal interactions: relevance for phytoremediation". Frontiers in Plant Science 7 (2016): 918.

10. Rifat H., et al. "Soil beneficial bacteria and their role in plant growth promotion: a review". Annals of Microbiology 60.4 (2010): 579-598.

11. Sadfi N., et al. "Journal of Plant Pathology 83 (2001): 101-118.

12. Sharma S., et al. "Biofilm: Used as A Brand-new Technology in Bioremediation". Vidya; A Journal of Gujarat University 16.2 (2021): 99-116.

13. Sharma S., et al. "Phytomining of Heavy Metals: A Green Technology to Sustainable Agriculture". International Journal of Innovative Research in Science, Engineering and Technology (IJIRSET) 10.6 (2021): 7527-7538.

14. Sharma S., et al. "Isolation of Heavy Metal Tolerant Rhizobacteria from Zawar Mines Area, Udaipur, Rajasthan, India". Bioscience Biotechnology Research Communication Special 13.1 (2020): 233-238.

15. Sharma Sarita., et al. "Elucidate the Influence of Heavy Metal on Bacterial Growth Isolated from a Mining Location and A Waste Dump: Using their Inducible Mechanism". The Current Trends in Biomedical Engineering and Biosciences 20.2 (2021): 556034.
16. Tawiah AA., et al. "Antibiotic producing microorganisms from River Wiwi, Lake Bosomtwe and the Gulf of Guinea at Doakor Sea Beach, Ghana". BMC Microbiology 12.1 (2012): 1-8.

17. $\mathrm{Xu}$ LQ., et al. "Isolation and determination of four potential antimicrobial components from Pseudomonas aeruginosa extracts". International Journal of Medical Sciences 14.13 (2017): 1368.

\section{Assets from publication with us}

- Prompt Acknowledgement after receiving the article

- Thorough Double blinded peer review

- Rapid Publication

- Issue of Publication Certificate

- High visibility of your Published work

Website: www.actascientific.com/

Submit Article: www.actascientific.com/submission.php Email us: editor@actascientific.com

Contact us: +919182824667 